\title{
PERAMALAN DENGAN METODE PEMULUSAN EKSPONENSIAL HOLT-WINTER DAN SARIMA (Studi Kasus: Jumlah Produksi Ikan (Ton) di Kota Sibolga Tahun 2000-2017)
}

\author{
EKO FACHROZI PUTRA, YUDIANTRI ASDI, MAIYASTRI \\ Program Studi S1 Matematika, \\ Fakultas Matematika dan Ilmu Pengetahuan Alam, Universitas Andalas, \\ Kampus UNAND Limau Manis Padang, Indonesia, \\ email: ekofachroziputra@yahoo.co.id
}

Diterima 9 Maret 2019 Direvisi 7 April $2019 \quad$ Dipublikasikan 7 Mei 2019

\begin{abstract}
Abstrak. Peramalan adalah metode untuk memperkirakan besarnya jumlah suatu data pada waktu yang akan datang berdasarkan data pada masa lampau yang dianalisis menggunakan metode statistika. Metode peramalan dibagi ke dalam dua kategori utama, yaitu metode kualitatif dan metode kuantitatif. Data produksi ikan mengandung unsur musiman dan termasuk dalam metode kuantitatif yang peramalannya menggunakan time series model. Penelitian ini dilakukan untuk menentukan model terbaik dalam meramalkan jumlah produksi ikan di Kota Sibolga. Model terbaik didapatkan dari perbandingan dua metode, yaitu metode pemulusan eksponensial Holt-Winter dan SARIMA. Hasil analisis menunjukkan bahwa peramalan dengan metode SARIMA lebih baik dari metode pemulusan eksponensial Holt-Winter dengan melihat tingkat kesalahan peramalan yang ditentukan dari nilai MAE, MSE, dan MAPE. Untuk peramalan jumlah produksi ikan di kota Sibolga digunakan model terbaik yaitu $\operatorname{SARIMA}(0,0,1)(0,0,1)^{4}$.
\end{abstract}

Kata Kunci: Forecasting, Time Series, Pemulusan eksponensial Holt-Winter, SARIMA

\section{Pendahuluan}

Negara Indonesia merupakan negara dengan sumber daya alam yang cukup melimpah, sebagai contoh di bidang perikanan. Pertambahan penduduk dan perubahan konsumsi masyarakat ke arah protein hewani yang lebih sehat mengakibatkan permintaan akan kebutuhan ikan di Indonesia terus meningkat dari tahun ke tahun. Kondisi ini yang mendorong produksi ikan di tiap-tiap daerah meningkat, termasuk kota Sibolga. Data produksi ikan ini merupakan data deret waktu (time series) yang dikumpulkan setiap tahun untuk mengetahui perkembangan hasil produksi. Sebagaimana diketahui, data deret waktu adalah data yang dikumpulkan, dicatat, atau diamati berdasarkan urutan waktu. Data deret waktu dapat digunakan untuk membuat peramalan dan hasil peramalannya digunakan sebagai bahan pertimbangan dalam suatu penelitian. Untuk menentukan metode peramalan yang digunakan pada data deret waktu, perlu diketahui pola dari data tersebut sehingga 
peramalan dengan metode yang sesuai pola data dapat dilakukan. Pola data dapat dibedakan menjadi empat jenis, yaitu pola horizontal, siklis, tren, dan musiman [3].

Pada data jumlah produksi ikan dapat dilihat bahwa terdapat unsur musiman yang terkandung di dalamnya, dimana terjadi fluktuasi secara periodik pada waktu tertentu. Kondisi ini membuat peneliti untuk membandingkan peramalan dengan metode pemulusan eksponensial Holt-Winter yang penerapannya dapat dilakukan langsung tanpa memperhatikan kestasioneran dan metode Seasonal Autoregressive Integrated Moving Average (SARIMA) yang penerapannya harus memenuhi asumsi kestasioneran terlebih dahulu. Dari perbandingan ini akan ditentukan metode terbaik dengan melihat tingkat kesalahan peramalan yang dihasilkan.

\section{Kajian Pustaka}

\subsection{Metode Pemulusan Eksponensial Holt-Winter}

Metode pemulusan eksponensial Holt-Winter merupakan metode yang dapat mengatasi faktor tren dan musiman yang muncul secara sekaligus pada data deret waktu. Metode ini didasarkan atas tiga unsur yaitu unsur data asli, tren dan musiman dengan memberikan tiga pembobotan berturut-turut dalam prediksinya, yaitu $\alpha, \beta$, dan $\gamma$. Koefisien $\alpha, \beta$, dan $\gamma$ terletak diantara 0 dan 1 yang ditentukan secara subjektif atau dengan meminimalkan nilai kesalahan dari peramalan [2].

Metode pemulusan eksponensial Holt-Winter dibagi menjadi dua model, yaitu model aditif dan multiplikatif. Perhitungan dengan model aditif dilakukan jika plot data asli menunjukkan fluktuasi musiman yang relatif stabil (konstan), sedangkan model multiplikatif digunakan jika plot data asli menunjukkan fluktuasi musiman yang bervariasi.

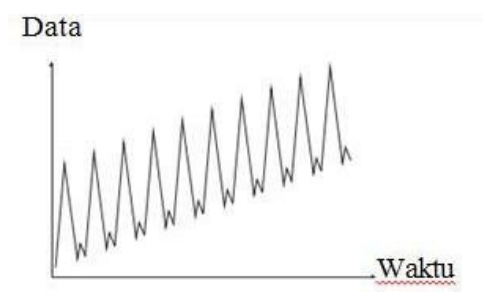

Gambar 1. Plot data asli model aditif

Persamaan-persamaan yang digunakan dalam model aditif, yaitu [1]

(1) Pemulusan eksponensial

$$
L_{t}=\alpha\left(X_{t}-S_{t-S}\right)+(1-\alpha)\left(L_{t-1}+T_{t-1}\right) .
$$

(2) Pemulusan pola tren

$$
T_{t}=\beta\left(L_{t}-L_{t-1}\right)+(1-\beta)\left(T_{t-1}\right) .
$$

(3) Pemulusan musiman

$$
S_{t}=\gamma\left(X_{t}-L_{t}\right)+(1-\gamma)\left(S_{t-S}\right) .
$$




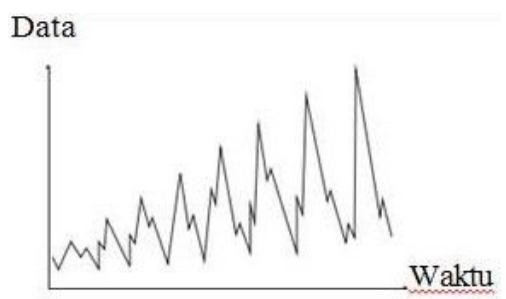

Gambar 2. Plot data asli model multiplikatif

(4) Ramalan pperiode ke depan

$$
\widehat{X}_{t+p}=L_{t}+p T_{t}+S_{t-S+p} .
$$

dengan

$$
\begin{aligned}
S_{t} & =\text { nilai pemulusan musiman pada waktu } t \\
\gamma & =\text { konstanta pemulusan untuk pola musiman } 0<\gamma<1 \\
S & =\text { periode musiman. }
\end{aligned}
$$

Persamaan-persamaan yang digunakan dalam model multiplikatif, yaitu :

(1) Pemulusan eksponensial

$$
L_{t}=\alpha\left(\frac{X_{t}}{S_{t-S}}\right)+(1-\alpha)\left(L_{t-1}+T_{t-1}\right) .
$$

(2) Pemulusan pola tren

$$
T_{t}=\beta\left(L_{t}-L_{t-1}\right)+(1-\beta)\left(T_{t-1}\right) .
$$

(3) Pemulusan musiman

$$
S_{t}=\gamma\left(\frac{X_{t}}{L_{t}}\right)+(1-\gamma)\left(S_{t-S}\right)
$$

(4) Ramalan pperiode ke depan

$$
\widehat{X}_{t+p}=\left(L_{t}+p T_{t}\right) S_{t-S+p}
$$

\subsection{Metode Seasonal Autoregressive Integrated Moving Average ( $S A R I M A)$}

Seasonal Autoregressive Integrated Moving Average (SARIMA) merupakan model ARIMA yang mengandung unsur musiman yang didefenisikan sebagai suatu pola yang berulang-ulang dalam periode musim. Untuk mengatasi adanya pola musiman pada data deret waktu, digunakan metode SARIMA dengan notasi umum $S A R I M A(p, d, q)(P, D, Q)^{S}$, dimana

$$
\begin{aligned}
(p, d, q) & =\text { bagian yang tidak musiman dari model, } \\
(P, D, Q) & =\text { bagian yang musiman dari model, } \\
S & =\text { panjang periode musiman. }
\end{aligned}
$$


Model SARIMA dapat dinyatakan dengan persamaan berikut [4]:

$$
\theta_{p}(B) \theta_{p}\left(B^{S}\right)\left(1-B^{S}\right)^{D} X_{t}=\theta_{q}(B) \Theta_{Q}\left(B^{S}\right) \varepsilon_{t}
$$

dimana

$$
\begin{aligned}
X_{t} & =\text { data deret waktu periode } T, \\
\theta_{p}(B) & =1-\theta_{1} B-\theta_{2} B-\cdots-\theta_{p} B, \\
\theta_{p}\left(B^{S}\right) & =1-\theta_{1} B^{S}-\theta_{2} B^{2 S}-\cdots-\theta_{p} B^{P S}, \\
(1-B)^{d} & =\text { differencing tidak musiman, } \\
\left(1-B^{S}\right)^{D} & =\text { differencing musiman, } \\
\theta_{q}(B) & =1-\theta_{1} B-\theta_{2} B-\cdots-\theta_{q} B, \\
\Theta_{Q}\left(B^{S}\right) & =1-\Theta_{1} B^{S}-\Theta_{2} B^{2 S}-\cdots-\Theta_{q} B^{Q S}, \\
\varepsilon_{t} & =\text { galat peramalan pada periode } t .
\end{aligned}
$$

Penentuan nilai $p$ dan $q$ dapat dibantu dengan acuan tabel berikut ini dengan mengamati pola fungsi autokorelasi dan autokorelasi parsial dari deret waktu.

Tabel 1. Karakteristik ACF dan PACF

\begin{tabular}{|c|c|c|}
\hline Model & ACF & PACF \\
\hline $\operatorname{AR}(p)$ & Dying down & Cut off setelah lag $p$ \\
\hline $\operatorname{MA}(q)$ & Cut off setelah lag $q$ & Dying down \\
\hline $\operatorname{ARMA}(p, q)$ & Dying down & Dying down \\
\hline $\operatorname{ARIMA}(p, d, q)$ & Dying down dengan pembedaan & Dying down dengan pembedaan \\
\hline
\end{tabular}

\subsection{Pemilihan Model Terbaik}

Penggunaan metode peramalan bergantung pada pola data yang akan dianalisis. Jika metode yang digunakan sudah dianggap benar untuk melakukan peramalan, maka pemilihan metode peramalan terbaik didasarkan pada tingkat kesalahan peramalan [3]. Jika galat yang dihasilkan semakin kecil, maka hasil peramalan akan semakin mendekati tepat. Besarnya galat tersebut dapat dihitung melalui ukuran galat peramalan, sebagai berikut.

(a) Mean Absolute Error (MAE)

Simpangan rata-rata MAD mengukur akurasi peramalan dengan meratakan nilai absolut galat peramalan. Nilai galat diukur dalam unit yang sama seperti pada data aslinya.

$$
M A E=\frac{1}{n} \sum_{t=1}^{n}\left|X_{t}-\widehat{X}_{t}\right|,
$$

dimana

$$
\begin{aligned}
n & =\text { banyaknya data yang diamati, } \\
\widehat{X}_{t} & =\text { peramalan ke }-t, \\
X_{t} & =\text { data ke }-t
\end{aligned}
$$


(b) Mean Squared Error (MSE)

Pada metode ini hampir sama dengan metode MAE hanya saja nilai kesalahannya dikuadratkan, rumus MSE adalah:

$$
M A E=\frac{1}{n} \sum_{t=1}^{n}\left(X_{t}-\widehat{X}_{t}\right)^{2}
$$

(c) Mean Absolute Percentage Error(MAPE)

Persentase galat rata-rata mutlak (MAPE) memberikan petunjuk seberapa besar galat peramalan dibandingkan dengan nilai sebenarnya. Suatu model data akan memiliki kinerja yang sangat baik apabila nilai MAPE dibawah $10 \%$.

$$
M A E=\frac{1}{n} \sum_{t=1}^{n}\left|\frac{X_{t}-\widehat{X}_{t}}{X_{t}}\right| x 100 \%
$$

\section{Data dan Hasil}

Data yang digunakan dalam penelitian ini adalah data sekunder yaitu data jumlah produksi ikan (ton) per-kuartal di kota Sibolga tahun 2000-2017 yang diperoleh dari Badan Pusat Statistik Kota Sibolga.

\subsection{Analisis Plot Data Produksi Ikan}

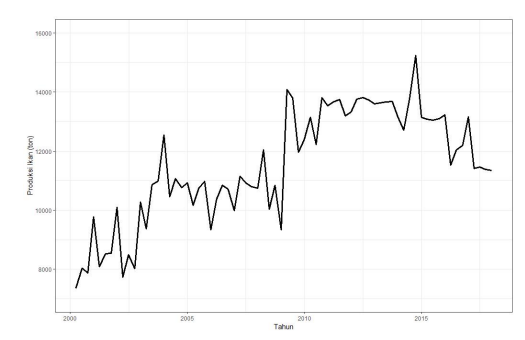

Gambar 3. Plot data jumlah produksi ikan kota Sibolga tahun 2000-2017

Dari plot data dapat diketahui bahwa data tidak stasioner terhadap nilai rataan sekaligus mempunyai pola musiman. Hal ini dapat dilihat dari plot kiri bawah ke kanan atas yang menandakan adanya fluktuasi meningkat dan pola data jumlah produksi ikan berulang pada kuartal tertentu.

\subsection{Metode Pemulusan Eksponensial Holt-Winter}

Pada plot data menunjukkan bahwa terjadi fluktuasi musiman yang konstan, sehingga model yang tepat digunakan adalah model aditif. Dengan menerapkan model aditif diperoleh konstanta pemulusan data asli $(\alpha)$ sebesar 0.34 , konstanta pemulusan untuk pola tren $(\beta)$ sebesar 0.06, dan konstanta pemulusan untuk pola musiman $(\gamma)$ sebesar 0.55. Dengan menggunakan konstanta pemulusan diperoleh persamaan model aditif sebagai berikut: 
80 Eko Fachrozi Putra, dkk

(1) Pemulusan eksponensial

$$
L_{t}=0.34\left(X_{t}-S_{t-S}\right)+(0.66)\left(L_{t-1}+T_{t-1}\right) .
$$

(2) Pemulusan pola tren

$$
T_{t}=0.06\left(L_{t}-L_{t-1}\right)+(0.94)\left(T_{t-1}\right) .
$$

(3) Pemulusan musiman

$$
S_{t}=0.55\left(X_{t}-L_{t}\right)+(0.45)\left(S_{t-S}\right) .
$$

(4) Ramalan $p$ periode ke depan

$$
\widehat{X}_{t+p}=L_{t}+p T_{t}+S_{t-S+p} .
$$

Berikut ini plot data asli dan hasil ramalan dari model aditif.

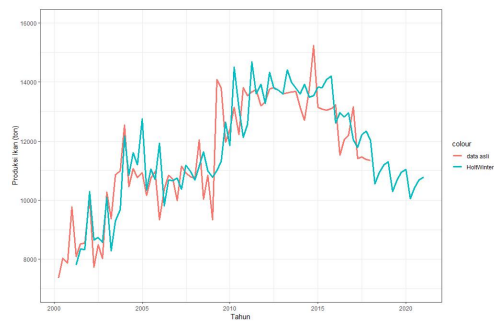

Gambar 4. Plot data asli dan hasil ramalan metode Holt-Winter

Dari Gambar 4 dapat dilihat bahwa selisih dari hasil ramalan dengan data asli cukup besar dan terlihat hasil ramalan sudah mengikuti data asli.

\subsection{Metode SARIMA}

Berikut ini grafik ACF dan PACF setelah dilakukan differencing:
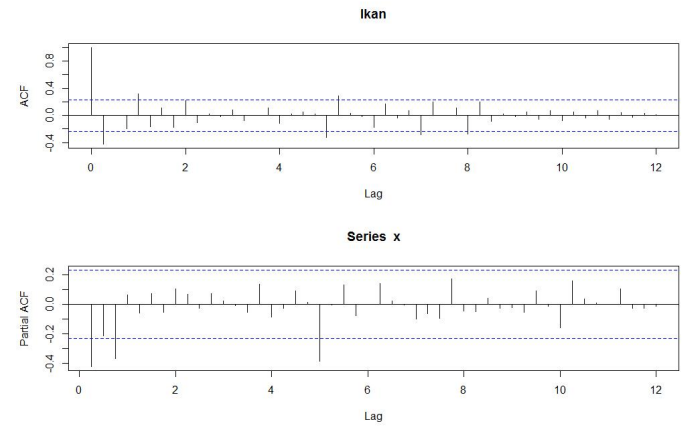

Gambar 5. Grafik differencing pertama 


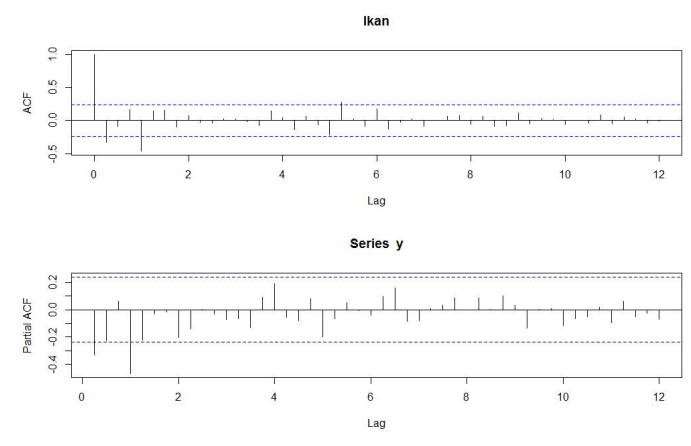

Gambar 6. Grafik differencing musiman

Dalam mendapatkan model, dilakukan identifikasi pada grafik ACF dan PACF sehingga diperoleh model awal dari metode SARIMA adalah SARIMA $(1,1,1)(1,1,1)^{4}$. Dengan menaikkan dan menurunkan orde dari model awal diperoleh beberapa kemungkinan model dengan parameter yang signifikan, yaitu:

Tabel 2. Model Dugaan yang Signifikan

\begin{tabular}{|c|c|c|c|}
\hline Model & Parameter & Taksiran Parameter & $p$-value \\
\hline \multirow{2}{*}{ SARIMA $(1,1,0)(1,1,0)^{4}$} & $\operatorname{AR}(1)$ & -0.34 & 0.0044 \\
& $\operatorname{SAR}(4)$ & -0.44 & 0.0001 \\
\hline \multirow{2}{*}{ SARIMA $(1,1,0)(0,1,1)^{4}$} & $\operatorname{AR}(1)$ & -0.37 & 0.0017 \\
& $\operatorname{SMA}(4)$ & -0.51 & 0.0000 \\
\hline \multirow{2}{*}{ SARIMA $(0,1,1)(1,1,0)^{4}$} & $\operatorname{MA}(1)$ & -0.57 & 0.0001 \\
& $\operatorname{SAR}(4)$ & -0.45 & 0.0001 \\
\hline \multirow{2}{*}{ SARIMA $(0,1,1)(0,1,1)^{4}$} & $\operatorname{MA}(1)$ & -0.60 & 0.0000 \\
& $\mathrm{SMA}(4)$ & -0.53 & 0.0000 \\
\hline
\end{tabular}

Untuk menentukan model terbaik dari metode Sarima digunakan kriteria kebaikan model dengan hasil sebagai berikut.

Tabel 3. Nilai AIC dan SC/BIC

\begin{tabular}{|c|c|c|c|c|c|c|}
\hline \multirow{2}{*}{ Model } & \multicolumn{2}{|c|}{ AIC } & \multicolumn{2}{c|}{ BIC } & Rata & Rank \\
\cline { 2 - 7 } & Nilai & Rank & Nilai & Rank & Rata & Akhir \\
\hline SARIMA $(1,1,0)(1,1,0)^{4}$ & 1129.47 & 4 & 1136.08 & 4 & 4 & 4 \\
\hline SARIMA $(1,1,0)(0,1,1)^{4}$ & 1127.45 & 3 & 1134.07 & 3 & 3 & 3 \\
\hline SARIMA $(0,1,1)(1,1,0)^{4}$ & 1124.32 & 2 & 1130.93 & 2 & 2 & 2 \\
\hline SARIMA $(0,1,1)(0,1,1)^{4}$ & 1121.70 & 1 & 1128.31 & 1 & 1 & 1 \\
\hline
\end{tabular}

Dari beberapa kemungkinan model tersebut terpilih model terbaik yaitu $\operatorname{SARIMA}(0,1,1)(0,1,1)^{4}$. Persamaaan model $\operatorname{SARIMA}(0,1,1)(0,1,1)^{4}$ dengan nilai taksiran parameter yang signifikan yaitu:

$$
X_{t}=0.32 \varepsilon_{t-5}+0.53 \varepsilon_{t-4}+0.60 \varepsilon_{t-1}+\varepsilon_{t} .
$$


Berikut ini plot data asli dan hasil ramalan dari model $\operatorname{SARIMA}(0,1,1)(0,1,1)^{4}$.

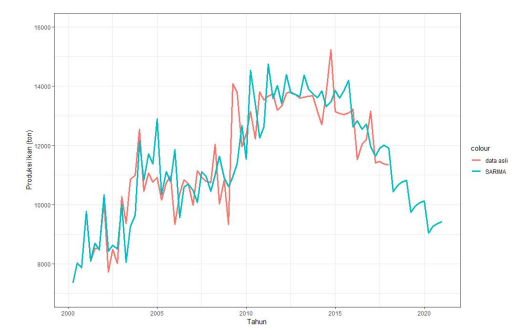

Gambar 7. Plot data asli dan hasil ramalan metode SARIMA

Gambar 7 menunjukkan bahwa selisih dari hasil ramalan dengan data asli cukup besar dan terlihat hasil ramalan sudah mengikuti data asli.

\subsection{Perbandingan Metode Eksponensial Holt-Winter dan SARIMA}

Untuk menentukan peramalan yang lebih tepat dari metode Holt-Winter dan SARIMA digunakan nilai MAE, MSE, dan MAPE.

Tabel 4. Tingkat Kesalahan Peramalan

\begin{tabular}{|c|c|c|c|}
\hline Model & MAE & MSE & MAPE \\
\hline Aditif & 743.29 & 945352.80 & 6.39 \\
\hline$S A R I M A(0,1,1)(0,1,1)^{4}$ & 693.11 & 903033.90 & 5.92 \\
\hline
\end{tabular}

Dari perbandingan nilai kesalahan peramalan di atas menunjukkan bahwa metode SARIMA lebih tepat digunakan dalam peramalan jumlah produksi ikan ini dengan model $S A R I M A(0,1,1)(0,1,1)^{4}$ karena menghasilkan tingkat kesalahan peramalan yang kecil. Berikut hasil peramalan model $S A R I M A(0,1,1)(0,1,1)^{4}$ untuk tiga tahun ke depan.

\begin{tabular}{|c|c|c|c|c|}
\hline \multicolumn{5}{|c|}{ Tabel 5. Hasil Peramalan } \\
\hline Tahun/Kuartal & Q1 & Q2 & Q3 & Q4 \\
\hline 2018 & 10433.23 & 10651.99 & 10757.97 & 10827.37 \\
\hline 2019 & 9739.37 & 9958.13 & 10064.10 & 10133.50 \\
\hline 2020 & 9045.50 & 9264.26 & 9370.24 & 9439.64 \\
\hline
\end{tabular}

\section{Kesimpulan}

Berdasarkan hasil peramalan yang dilakukan dengan metode pemulusan eksponensial Holt-Winter dan SARIMA dapat diambil kesimpulan sebagai berikut:

(1) Peramalan jumlah produksi ikan di kota Sibolga dengan metode eksponensial Holt-Winter menunjukkan bahwa model dari data adalah model aditif dengan konstanta pemulusan $\alpha=0.34, \beta=0.06$, dan $\gamma=0.55$. 
(2) Pada peramalan jumlah produksi ikan di kota Sibolga dengan metode SARIMA diperoleh model terbaik dari beberapa kemungkinan model yaitu $\operatorname{SARIMA}(0,1,1)(0,1,1)^{4}$.

(3) Dari perbandingan yang dilakukan dapat diketahui bahwa peramalan jumlah produksi ikan dengan metode SARIMA lebih baik dari pada metode eksponensial Holt-Winter.

\section{Ucapan Terima Kasih}

Penulis mengucapkan terima kasih kepada Ibu Izzati Rahmi HG, M.Si, Ibu Dr. Lyra Yulianti dan Bapak Zulakmal, M.Si yang telah memberikan bimbingan, kritik dan saran dalam penyelesaian makalah ini.

\section{Daftar Pustaka}

[1] Hanke, J.E. dan D.W. Wichern. 2005. Business Forecasting Eight Edition. Pearson Prentice Hall, New Jersey.

[2] Makridakis, S., Wheelwright, S.C., dan McGee, V.E. 1999. Metode dan Aplikasi Peramalan Jilid 1. Terjemahan Ir. Untung Sus Ardiyanto, M.Sc. dan Ir. Abdul Basith, M.Sc. Edisi Kedua. Penerbit Erlangga, Jakarta

[3] Santoso, S. 2009. Business Forecasting: Metode Peramalan Bisnis Masa Kini dengan MINITAB dan SPSS. PT. Elex Media Komputindo, Jakarta.

[4] Wei, W.W.S. 2006. Time Series Analysis: Univariate and Multivariate Methods. Addison Wesley, Canada. 